\title{
Investigation of Heat Extraction Methods from Cuprous Chloride for Improving the Efficiency of the Thermochemical Copper-Chlorine Cycle
}

\author{
Sukhpreet S. Manan ${ }^{1}$, Ofelia A. Jianu ${ }^{2}$, Marc A. Rosen ${ }^{1}$ \\ ${ }^{1}$ Faculty of Engineering and Applied Science, University of Ontario Institute of Technology, Oshawa, Ontario, CANADA \\ 2 Faculty of Engineering, University of Windsor, Windsor, Ontario, CANADA
}

*Corresponding Author: ofelia.jianu@uwindsor.ca

Citation: Manan, S. S., Jianu, O. A. and Rosen, M. A. (2019). Investigation of Heat Extraction Methods from Cuprous Chloride for Improving the Efficiency of the Thermochemical Copper-Chlorine Cycle. European Journal of Sustainable Development Research, 3(1), em0075. https:/ /doi.org/10.20897/ ejosdr/3976

Published: February 6, 2019

\begin{abstract}
In order to improve the efficiency of the thermochemical copper-chlorine cycle $(\mathrm{Cu}-\mathrm{Cl})$ for hydrogen production, a quench cell configuration for the quenching of cuprous chloride $(\mathrm{CuCl})$ is being investigated. Initial testing has been performed in water to determine whether the molten cuprous chloride can be cooled enough to be quenched in hydrochloric acid ( $\mathrm{HCl}(\mathrm{aq}))$. Quenching in $\mathrm{HCl}(\mathrm{aq})$ would reduce the number of components in the overall cycle, simplifying it and potentially making it more cost effective. A thermal camera was used to experimentally obtain the heat loss as the $\mathrm{CuCl}$ falls through the heat exchanger and into the quench cell. In addition, a FlowSense $2 \mathrm{M}$ shadow imaging camera was used to observe the behavior of the $\mathrm{CuCl}$ droplets interacting with the quench solution. It was observed that the $\mathrm{CuCl}$ droplet disintegrating into dust like particles as it enters the water pool and vapour was generated hence the temperature at the surface of the droplet as it entered the liquid water exceeded $100{ }^{\circ} \mathrm{C}$.
\end{abstract}

Keywords: hydrogen production, copper chlorine cycle, quench cell, heat exchanger

\section{INTRODUCTION}

As the demand for energy increases, so do the challenges of producing enough fuel to meet the demand. Currently fossil fuels are the main source of energy in the world. Fossil fuels however are finite in supply, and contribute $79 \%$ of the total US greenhouse gas emissions (Marques et al., 2018). In order to meet future energy demands, alternative energy sources and means of energy production need to be considered.

One alternative fuel is hydrogen. Although hydrogen is not an energy resource itself, it is an energy carrier that can facilitate the use of many sustainable energy resources (Alanne and Cao, 2017; McDowall, 2012). Hydrogen is the most abundant element, making up roughly $90 \%$ of all the atoms in the universe. On earth, however, hydrogen is present mainly in water $\left(\mathrm{H}_{2} \mathrm{O}\right)$, as opposed to hydrogen gas $\left(\mathrm{H}_{2}\right)$. Currently, hydrogen is mainly produced from natural gas using steam-methane reforming (McDowall and Eames, 2006). Since natural gas is a finite resource and since its use leads to environmental and other problems, it is necessary to explore other methods. Another method currently used for hydrogen production is water electrolysis. A challenge with this method is its efficiency, defined as the ratio of the energy in the hydrogen produced to the electrical energy input. The efficiency of water electrolysis is approximately $24 \%$ (Lewis et al., 2009). An alternative process to produce $\mathrm{H}_{2}$ in an efficient and a clean manner that exhibits significant potential is thermochemical water decomposition (Rosen et al., 2012; Naterer et al., 2010; Naterer et al., 2011; Dincer, 2012). 


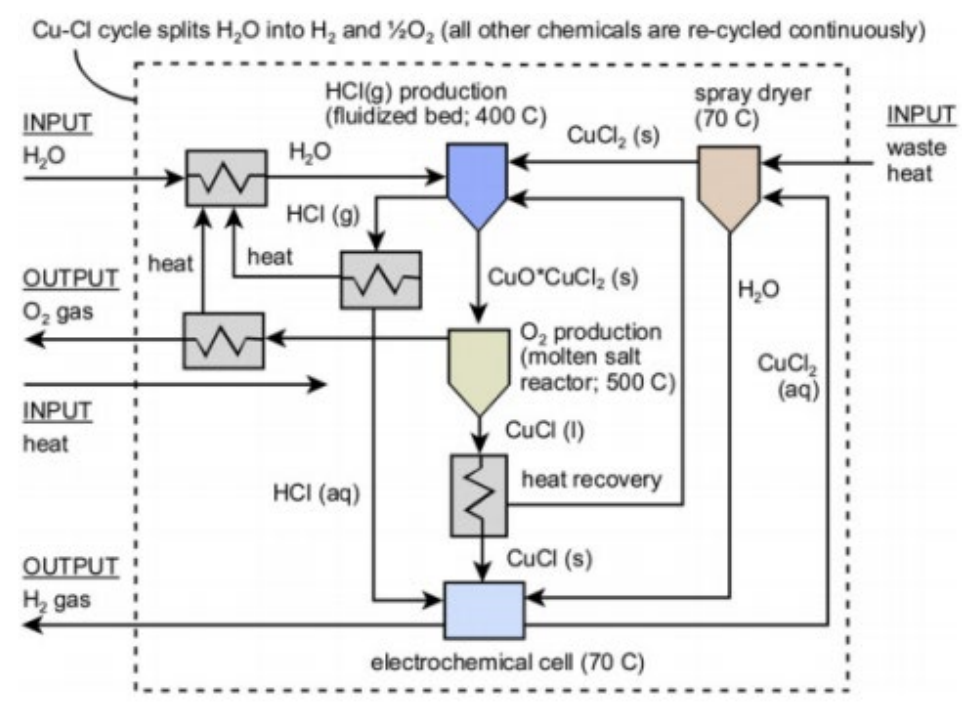

Figure 1. Schematic of the four-step $\mathrm{Cu}-\mathrm{Cl}$ cycle (Naterer et al., 2010)

Table 1. Main chemical reactions of the $\mathrm{Cu}-\mathrm{Cl}$ cycle

\begin{tabular}{cll}
\hline Step & Reaction & Tempeature Range $\left({ }^{\circ} \mathbf{C}\right)$ \\
\hline 1 & $2 \mathrm{CuCl}_{(\mathrm{aq})}+2 \mathrm{HCI}(\mathrm{aq}) \rightarrow \mathrm{H}_{2}(\mathrm{~g})+2 \mathrm{CuCl}_{2}(\mathrm{aq})$ & $<100$ (electrolysis) \\
\hline 2 & $\mathrm{CuCl}_{2}(\mathrm{aq}) \rightarrow \mathrm{CuCl}_{2}(\mathrm{~s})$ & $<100$ \\
\hline 3 & $2 \mathrm{CuCl}_{2}(\mathrm{~s})+\mathrm{H}_{2} \mathrm{O}(\mathrm{g}) \rightarrow \mathrm{CuO} * \mathrm{CuCl}_{2}(\mathrm{~s})+2 \mathrm{HCl}(\mathrm{g})$ & 400 \\
\hline 4 & $\mathrm{CuO}^{*} \mathrm{CuCl}_{2}(\mathrm{~s}) \rightarrow 2 \mathrm{CuCl}(\mathrm{l})+\frac{\mathbf{1}}{\mathbf{2}} \mathrm{O}_{2}$ & 500 \\
\hline
\end{tabular}

Source (Naterer et al., 2010)

One thermochemical water decomposition process that has received increasing attention in recent years is a four-step thermochemical Cu-Cl cycle (Naterer et al., 2009). The overall $\mathrm{Cu}-\mathrm{Cl}$ cycle is complex. A simplified version of it is shown in Figure 1, where it is seen to involve four main chemical reactions. In Table 1, the four main steps of the four-step $\mathrm{Cu}-\mathrm{Cl}$ cycle are listed. The overall nature of the process can be observed from the chemical reactions taking place. An important step in the four-step $\mathrm{Cu}-\mathrm{Cl}$ cycle involves converting the liquid $\mathrm{CuCl}$ in step 4 (Table 1) into an aqueous state by dissolving it in $\mathrm{HCl}$ (aq). The liquid $\mathrm{CuCl}$ after step 4 is in a molten state, being exposed to temperatures higher than its melting point. In order to prep the molten $\mathrm{CuCl}$ for step 1, the molten $\mathrm{CuCl}$ is quenched in a quench cell and then dissolved in $\mathrm{HCl}$ (aq). Given that the temperature of the $\mathrm{CuCl}$ is high when exiting step 4, the use of a heat exchanger can aid in heat recovery while cooling the molten $\mathrm{CuCl}$ from roughly $500{ }^{\circ} \mathrm{C}$ to a room temperature of $25^{\circ} \mathrm{C}$. There are three modes of heat transfer: conduction, convection and radiation (Cengel, 2006). In order to determine the most applicable heat extraction method, current heat extraction methods were explored. Heat transfers from high to low temperature, therefore it would be essential to ensure that the ambient temperature that the experiments conducted are as low as possible. Numerous studies have been conducted in the past regarding heat recovery methods that can be used in the $\mathrm{Cu}-\mathrm{Cl}$ thermochemical cycle. These methods include atomization and steam generation with a quench bath (Ghandehariun et al., 2011), as well as a double-pipe heat exchanger (Ghandehariun et al., 2012).

An experiment is carried out to investigate this heat transfer. To observe the heat transfer during the experiment, a thermal camera is used. If a temperature of roughly $25^{\circ} \mathrm{C}$ can be obtained with the heat exchanger, the $\mathrm{CuCl}$ can be quenched directly in $\mathrm{HCl}(\mathrm{aq})$, which implies the possible removal of the dissolution cell and ultimately reducing the cost of the overall setup. However, if a temperature of $25{ }^{\circ} \mathrm{C}$ is unattainable, the heat exchanger will be designed to achieve temperature of $100{ }^{\circ} \mathrm{C}$ and then quenched in water. In addition, how the molten $\mathrm{CuCl}$ behaves when it interacts with the surface of the quench liquid was examined. For example, does the molten $\mathrm{CuCl}$ form one solid mass, or break into many very small particles that easily dissolve in the quench solution. In order to observe this, a shadow imaging and fluid particle analysis software is used. The objective of this research paper is to improve understanding of waste heat extraction methods for the $\mathrm{Cu}-\mathrm{Cl}$ thermochemical cycle and the behavior of molten $\mathrm{CuCl}$ in quench solution. Such an understanding is important for decision making on which measures to use to increase the efficiency of the cycle. Extracting the waste heat from the molten $\mathrm{CuCl}$ is beneficial to the overall system because the heat can be recycled into the cycle. This reduces the heat input required and thereby increases the efficiency of the cycle (Ghandehariun et al., 2016; Jaber et al., 2010). 


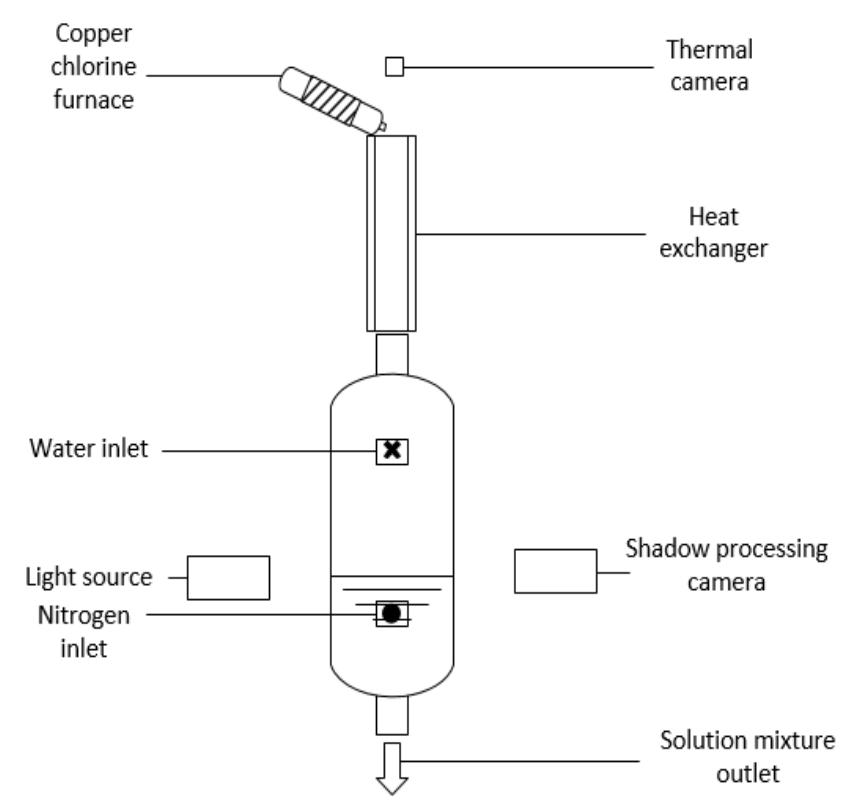

Figure 2. Schematic of experimental setup

\section{APPROACH AND METHODOLOGY}

In order to conduct this experiment a quench cell assembly was proposed, designed and assembled. The experimental set up is illustrated in Figures 2 and 3. The quench cell assembly consists of a $25 \mathrm{~L}$ glass vessel, a heat exchanger, aluminum bars, and an insulated small glass tube wrapped in heating tape, as well as a thermal camera and a shadow imaging camera. The quench cell was equipped with valves at the water inlet, the nitrogen inlet, and the slurry outlet. The water inlet was connected to a water pump and a water reservoir and the nitrogen inlet was connected to a nitrogen tank. A pipe was added to connect the slurry outlet and a collection bucket. A pyrex Allihn condenser was installed between the molten salt reactor and the quench cell such that no air could enter the system to prevent oxidation of the $\mathrm{CuCl}$. The condenser would ensure that the gasses rising during the quenching process are being condensed back into the cell so that the concentration is maintained constant and backflow into the decomposition reactor is prevented. The shadow imaging camera and the thermal camera were fixed onto the main frame by creating adjustable side supports from aluminum bars. After the installation of the cameras, they were configured in order to achieve accurate results. A small furnace was assembled to melt the $\mathrm{CuCl}$ and simulate the overflow from the decomposition reactor. The furnace consists of a glass tube that is open on one end to permit insertion of the $\mathrm{CuCl}$ powder, and an orifice on the other end for the molten $\mathrm{CuCl}$ to drip into the condenser. In order to obtain a temperature of $500{ }^{\circ} \mathrm{C}$, a heat tape was wrapped around the tube and then insulated to reduce heat losses from the tube to the atmosphere.

The quench vessel was filled with water and the system was purged with nitrogen gas. The $\mathrm{CuCl}$ furnace was allowed to reach a steady state temperature of $500^{\circ} \mathrm{C}$. Once the temperature was achieved, $24.5 \mathrm{~g}$ of $\mathrm{CuCl}$ powder was poured into the open end of the mini $\mathrm{CuCl}$ furnace and then closed with insulation to prevent the melting $\mathrm{CuCl}$ from oxidizing in air (Jianu et al., 2018). Meanwhile the cameras were set to start recording as the molten $\mathrm{CuCl}$ drips out of the furnace. As each drop developed and detached, the thermal camera recorded the temperature change in the droplet whereas the shadow imaging camera recorded the behavior of the $\mathrm{CuCl}$ droplet as it collided with the surface of the water in the quench vessel. The droplet traveled a distance of $1.5 \mathrm{~m}$ from detachment to collision with water surface as shown in Figures 2 and 3.

\section{RESULTS AND DISCUSSION}

To effectively determine the method that offers the most recovery of waste heat, multiple tests were conducted. In each said test, the rate of heat transfer from the molten $\mathrm{CuCl}$ and the interaction between the molten $\mathrm{CuCl}$ and the aqueous quench solution were observed. Overall, three variations for the quench cell assembly were or are to be examined. The first variation for the quench cell assembly consisted of dropping the $\mathrm{CuCl}$ into the heat exchanger and having the heat transfer occur with the ambient air and then quenching the $\mathrm{CuCl}$ in water at the 


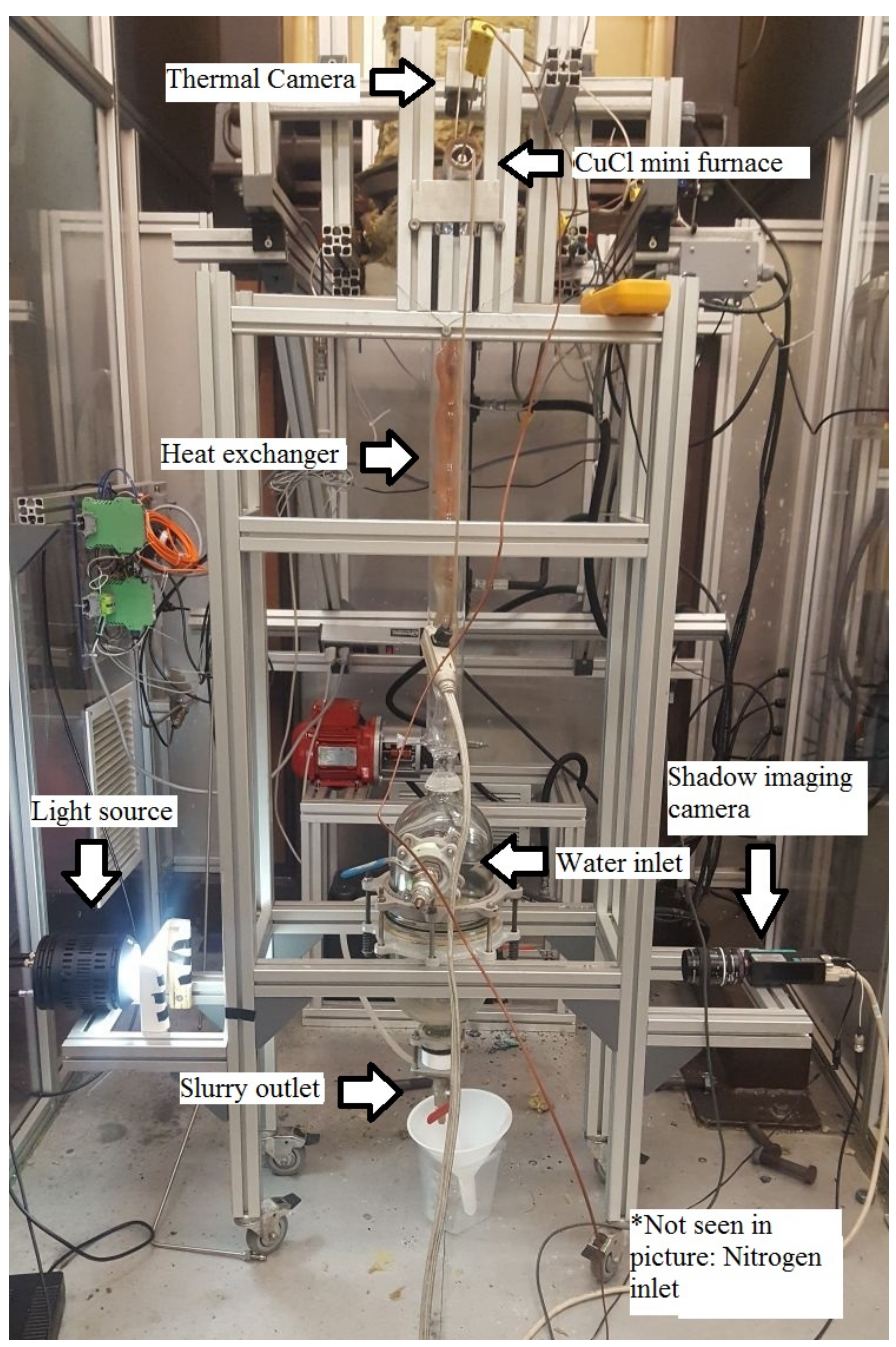

Figure 3. Experimental setup

bottom. Using this variation, two runs of experiment were conducted and it was observed the $\mathrm{CuCl}$ cools to an average of $385^{\circ} \mathrm{C}-410{ }^{\circ} \mathrm{C}$. With heat transfer only to the air, it was observed that the only $30 \%$ of the waste heat was removed from the molten $\mathrm{CuCl}$ droplets. In order to increase the percentage of waste heat removed from the $\mathrm{CuCl}$ droplet and the ambient air, the distance between the tip of the furnace and the quench solution can be increased.

The shadow imaging camera recorded the interaction between the $\mathrm{CuCl}$ and the water. The obtained images were then analyzed using the shadow processing function in Dynamic Studio. It was observed that the $\mathrm{CuCl}$ dispersed into numerous small particles. An image of the interaction obtained from each run can be seen in Figure 4. The one on the left is run 1 and on the right is run 2. As seen in the images, the $\mathrm{CuCl}$ droplets behaved similarly both times when hitting the water. It was observed that the $\mathrm{CuCl}$ particles settled at the bottom of the water tank which is expected since it is not soluble in water (Jianu et al., 2013; Jianu et al., 2016).

The last variation for the proposed setup is to have a gas rise from the bottom of the heat exchanger to the top of the heat exchanger. This method can be beneficial in two ways. For example, depending on the choice of gas, its thermal conductivity can be higher than that of air and therefore can be coupled with a liquid flowing through the outer shell of the heat exchanger to further improve the heat extraction occurring. In addition, the air would be opposing the motion of the falling droplet, and increase the duration of the droplet in the air. Before any experimentation could occur with counter-flowing gas, it was important to identify the ideal gas for the scenario using a criteria matrix. Nitrogen was selected as the counter flow gas since it purges oxygen thus preventing the oxidation of $\mathrm{CuCl}$ to other undesirable complexes. An additional consideration is to observe if the counter-flow gas will affect the particles interaction with the quench solution. In order to achieve accurate results, multiple tests should be conducted. During experimentation a temperature drop from $450{ }^{\circ} \mathrm{C}$ to approx. $325{ }^{\circ} \mathrm{C}$ was observed at the surface of the droplet. The shadow imaging camera observed that the interaction of the $\mathrm{CuCl}$ droplet and the quench solution was unchanged. 

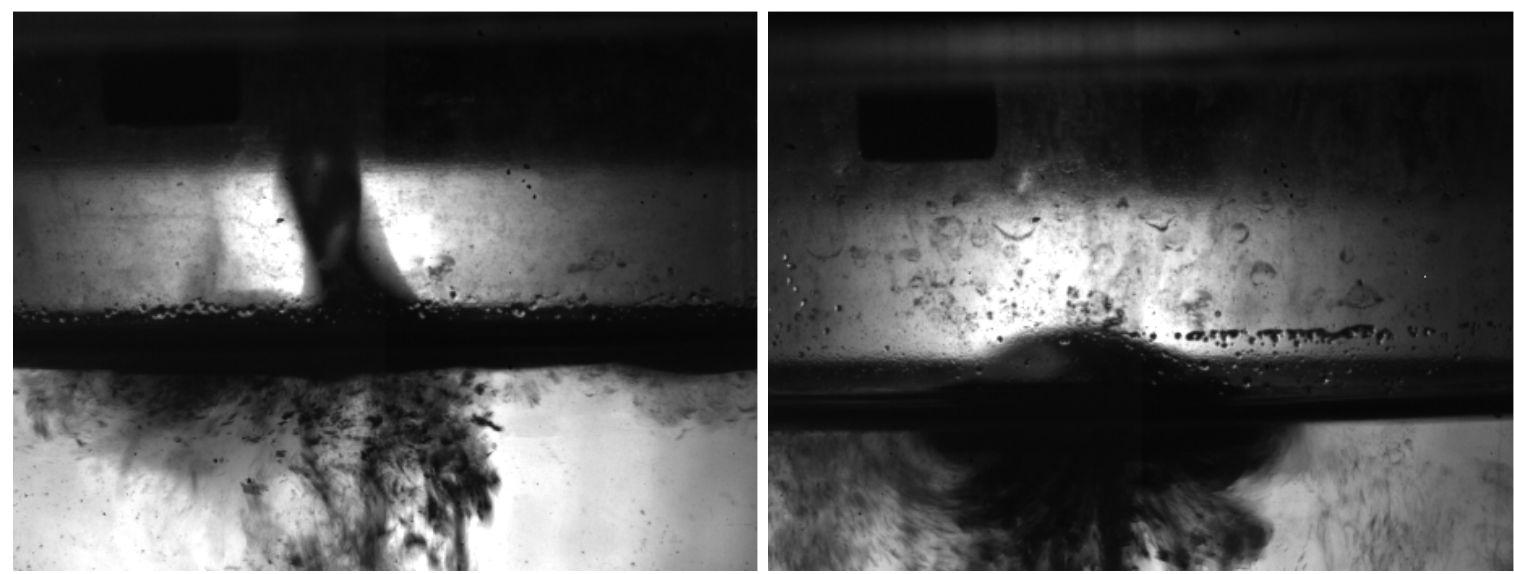

Figure 4. Shadow images obtained from quenching molten $\mathrm{CuCl}$ in water with natural convection as heat recovery method

The second variation uses the heat exchanger and involves running chilled water on the outside to extract heat from the droplet. This method however is inefficient at such a small scale. Since the thermal conductivity of the air is low and the size of the drop is small relative to the heat exchanger, the rate of heat transfer does not change significantly from variation 1 . Therefore, in order to ensure that the obtained results are of use, changes to either the droplet size or diameter of the heat exchanger would be necessary.

\section{CONCLUSIONS}

A quench cell assembly that will improve the efficiency of the thermochemical $\mathrm{Cu}-\mathrm{Cl}$ cycle was designed and assembled. In addition to improving efficiency, an investigation into methods of recovering the waste heat was conducted. If the heat can be extracted such that the $\mathrm{CuCl}$ cools to room temperature, then the $\mathrm{CuCl}$ can be quenched in $\mathrm{HCl}$ directly. The result can be removing the need of a dissolution cell in the cycle and reducing the cost of the overall cycle. Three variations were examined based on the same general design. The first variation involves natural convection of the heat to ambient air. The second variation involves the use of a chilled water blanket. This method however was unfavorable given the scale of the experiments, so the results obtained for this variation have little significance in determining the best heat extraction method. The last variation explored is floating nitrogen gas through the heat exchanger opposing the motion of the falling droplet. Based on results from the experimentation conducted, extracting the waste heat so the final temperature is about $25^{\circ} \mathrm{C}$ is not possible with any heat exchanger; hence quenching in $\mathrm{HCl}$ would not be advisable as $\mathrm{HCl}$ vapour would be formed which would rise and potentially enter the decomposition reactor, causing a safety concern.

\section{ACKNOWLEDGMENTS}

Support of this research from Canadian Research Laboratories, the Natural Sciences and Engineering Research Council of Canada and the Ontario Research Fund is gratefully acknowledged.

\section{REFERENCES}

Alanne, K. and Cao, S. (2017). Zero-energy hydrogen economy (ZEH2E) for buildings and communities including personal mobility. Renew. Sustain. Energy Rev., 71, 697-711. https:// doi.org/10.1016/j.rser.2016.12.098

Cengel, Y. A. (2006). Heat and Mass Transfer: A Practical Approach, 687-688.

Dincer, I. (2012). Green methods for hydrogen production. Int. J. Hydrogen Energy, 37(2), 1954-1971. https://doi.org/10.1016/j.ijhydene.2011.03.173

Ghandehariun, S., Rosen, M. A., Naterer, G. F. and Wang, Z. (2011). Comparison of molten salt heat recovery options in the $\mathrm{Cu}-\mathrm{Cl}$ cycle of hydrogen production. Int. J. Hydrogen Energy, 36(17), 11328-11337. https:// doi.org/10.1016/j.ijhydene.2010.11.093

Ghandehariun, S., Rosen, M. A., Naterer, G. F. and Wang, Z. (2012). Pinch analysis for recycling thermal energy in the $\mathrm{Cu}-\mathrm{Cl}$ cycle. Int.J. Hydrogen Energy, 37(21), 16536-16541. https://doi.org/10.1016/j.ijhydene.2012.06.081 
Ghandehariun, S., Rosen, M. A. and Naterer, G. F. (2016). Direct contact heat transfer from molten salt droplets in a thermochemical water splitting process of hydrogen production. Int. J. Heat Mass Transf., 96, $125-131$. https://doi.org/10.1016/j.ijheatmasstransfer.2015.12.063

Jaber, O., Naterer, G. F. and Dincer, I. (2010). Heat recovery from molten $\mathrm{CuCl}$ in the Cu-Cl cycle of hydrogen production. Int. J. Hydrogen Energy, 35(12), 6140-6151. https:// doi.org/10.1016/j.ijhydene.2010.03.041

Jianu, O. A., Wang, Z., Naterer, G. F. and Rosen, M. A. (2018). Constituent solubility and dissolution in a CuClHCl-H2O ternary system. Chem. Eng. Sci., 184, 209-215. https://doi.org/10.1016/j.ces.2018.03.004

Jianu, O. A., Wang, Z., Rosen, M. A. and Naterer, G. F. (2013). Shadow imaging of particle dynamics and dissolution rates in aqueous solutions for hydrogen production. Exp. Therm. Fluid Sci., 51, $297-301$. https://doi.org/10.1016/j.expthermflusci.2013.08.012

Jianu, O. A., Wang, Z., Rosen, M. A. and Naterer, G. F. (2016). Experimental investigation of particle dissolution rates in aqueous solutions for hydrogen production. Heat Mass Transf., 52(10), $2067-2073$. https:// doi.org/10.1007/s00231-015-1724-y

Lewis, M. A., Ferrandon, M. S., Tatterson, D. F. and Mathias, P. (2009). Evaluation of alternative thermochemical cycles - Part III further development of the Cu-Cl cycle. Int. J. Hydrogen Energy, 34(9), 4136-4145. https:// doi.org/10.1016/j.ijhydene.2008.09.025

Marques, A. C., Fuinhas, J. A. and Pereira, D. A. (2018). Have fossil fuels been substituted by renewables? An empirical assessment for 10 European countries. Energy Policy, 116, $257-265$. https://doi.org/10.1016/j.enpol.2018.02.021

McDowall, W. (2012). Technology roadmaps for transition management: The case of hydrogen energy. Technol. Forecast. Soc. Change, 79(3), 530-542. https:// doi.org/10.1016/j.techfore.2011.10.002

McDowall, W. and Eames, M. (2006). Forecasts, scenarios, visions, backcasts and roadmaps to the hydrogen economy: A review of the hydrogen futures literature. Energy Policy, 34(11), 1236-1250. https://doi.org/10.1016/j.enpol.2005.12.006

Naterer, G. F., Suppiah, S., Stolberg, L., Lewis, M., Wang, Z., Daggupati, V., Gabriel, K., Dincer, I., Rosen, M. A., Spekkens, P., Lvov, S. N., Fowler, M., Tremaine, J., Mostaghimi, P., Easton, E. B., Trevani, L., Rizvi, G., Ikeda, B. M., Kaye, M. H., Lu, L., Pioro, I., Smith, W. R., Secnik, E., Jiang, J. and Avsec, J. (2010). Canada's program on nuclear hydrogen production and the thermochemical $\mathrm{Cu}-\mathrm{Cl}$ cycle. Int. J. Hydrogen Energy, 35(20), 1090510926. https://doi.org/10.1016/j.ijhydene.2010.07.087

Naterer, G. F., Suppiah, S., Stolberg, L., Lewis, M., Ferrandon, M., Wang, Z., Dincer, I., Gabriel, K., Rosen, M. A., Secnik, E., Easton, E. B., Trevani, L., Pioro, I., Tremaine, P., Lvov, S., Jiang, J., Rizvi, G., Ikeda, B. M., Lu, L., Kaye, M., Smith, W. R., Mostaghimi, J., Spekkens, P., Fowler, M. and Avsec, J. (2011). Clean hydrogen production with the $\mathrm{Cu}-\mathrm{Cl}$ cycle - Progress of international consortium, I: Experimental unit operations. Int. J. Hydrogen Energy, 36(24), 15486-15501. https://doi.org/10.1016/j.ijhydene.2011.08.013

Naterer, G., Suppiah, S., Lewis, M., Gabriel, K., Dincer, I., Rosen, M. A., Fowler, M., Rizvi, G., Easton, E. B., Ikeda, B. M., Kaye, M. H., Lu, L., Pioro, I., Spekkens, P., Tremaine, P., Mostaghimi, J., Avsec, J. and Jiang, J. (2009). Recent Canadian advances in nuclear-based hydrogen production and the thermochemical $\mathrm{Cu}-\mathrm{Cl}$ cycle. Int. J. Hydrogen Energy, 34(7), 2901-2917. https:/ / doi.org/10.1016/j.ijhydene.2009.01.090

Rosen, M. A., Naterer, G. F., Chukwu, C. C., Sadhankar, R. and Suppiah, S. (2012). Nuclear-based hydrogen production with a thermochemical copper-chlorine cycle and supercritical water reactor: Equipment scale-up and process simulation. Int. J. Energy Res., 36(4), 456-465. https://doi.org/10.1002/er.1702 